Journal of

Epilepsy and

Clinical

Neurophysiology
Patrocinador desta seção:

(1) NOVARTIS

Editor convidado:

ANDRÉ PALMINI

\title{
Creutzfeldt-Jakob’s Disease - Case Report With Emphasis on the Electroencephalographic Features
}

\author{
Patrícia Coral*,**, Francisco M. B. Germiniani*, Carlos E. Silvado*,**,*** \\ Epicentro - Centro Integrado de Atendimento de Epilepsia, Curitiba, PR
}

\begin{abstract}
Creuzfeldt-Jakob's Disease is a rare neurodegenerative disorder that is included among the transmissible spongiform encephalopathies. The clinical features are those of a rapid progressive dementia with mioclonic jerks, which progresses to death in less than one year. We report the case of a 79 years old woman, with initial complaints of vertigo, visual and gait compromise, with an initial brain MRI, EEG and CSF that had no specific features of CJD. After 12 days she was again admitted to the hospital with a worsening of her symptoms, along with global spasticity, inability to walk and a further deterioration of speech and swallowing. A new EEG disclosed periodic triphasic complexes, typical of the disease. CSF had a positive 14-3-3 protein. She later evolved with mioclonic jerks, coma, multiple infectious complications and, ultimately, death 45 days after her second admission. We focus on the role of the EEG as an adjuctive eletrophysiological tool for the presumptive in vivo diagnosis of the disease.
\end{abstract}

Key words: dementia, Creutzfeldt-Jakob's Disease, prion.

\section{RESUMO}

Doença de Creutzfeldt-Jakob - Relato de caso com enfoque nos aspectos eletrencefalográficos

A Doença de Creuzfeldt-Jakob é uma rara desordem neurodegenerativa, que faz parte das encefalopatias espongiformes transmissíveis. Apresenta-se com um quadro de demência rapidamente progressiva, associada a mioclonias, que geralmente leva ao óbito em menos de um ano. Apresentamos um caso de uma mulher, 79 anos, com quadro inicial de vertigem, alteração visual, dificuldade de marcha. Inicialmente foram realizados ressonância magnética do crânio, EEG e liquor que não evidenciaram alterações especificas da doença. Após 12 dias reinternou com piora do quadro, espasticidade nos quatro membros, não deambulava, emitia sons incompreensíveis e não se alimentava. Novo EEG revelou os complexos de ondas trifásicas periódicos típicos da doença. A pesquisa da proteína 14-3-3 no líquor foi positiva. A paciente evoluiu com mioclonias, coma e múltiplas complicações infecciosas, vindo a óbito 45 dias após a internação. O presente artigo dá ênfase ao valor do armamentário eletrofisiológico (EEG) no contexto que leva ao diagnóstico presuntivo da doença in vivo.

Unitermos: demência, Doença de Creutzfeldt-Jakob, prion.

Creutzfeldt-Jakob's Disease (DCJ) is a rare, neurodegenerative disorder that is part of a larger group of transmissible spongiform encephalopathies ${ }^{(1)}$. It was first described by Gerhard Creutzfeldt e Alfons Jakob(2) in Germany last century, during the twenties. It was initially believed to be an infectious disease caused transmitted by an unconventional virus, which was later termed "prion" (proteinaceous infectious particle) by Prusiner in $1982^{(3)}$ nowadays, four different forms of the disease are recognized:

\footnotetext{
* Neurologista. Serviço e de Eletrencefalografia - Hospital de Clínicas da UFPR, Curitiba, PR.

** Neurofisiologista. Epicentro - Centro de Atendimento Integral de Epilepsia e Distúrbios do Sono - Hospital e Clínica de Fraturas XV, Curitiba, PR.

*** Professor adjunto. UFPR, Curitiba, PR.

Received July 20, 2005; accepted Aug. 29, 2005.
} 
1. Sporadic - which accounts for $87 \%$ of all cases;

2. Genetically transmitted (familial) - accounts for another $10 \%$ of reported cases;

3. Iatrogenical - which can either be transmitted by contaminated surgical instruments or human tissues (dura-mater grafts; growth hormone preparations, cornea grafts and intracranial cortical electrodes) ${ }^{(4)}$;

4. Variant form - which is the clinical form related to the bovine spongiform encephalopathy epidemic (the so-called "Mad Cow Disease") (5).

The disease manifests itself in those individuals who have a pathogenic isoform (PrPSC) of a protein normally found in our body (PrPC), which is then converted into the prion $(\mathrm{PrP})$ found in infected brains. Prions can arise due to a mutation of the gene responsible for the synthesis of the protein under the influence of an environmentally found prion (sporadic form), or conversely without such exposure in the familial form of the disease ${ }^{(6)}$. The familial form is inherited in a dominant autossomical pattern, where homozygosis for polymorphic expression of the 129 codon of the gene which expresses the protein can increase the susceptibility to prion infection ${ }^{(6)}$.

The estimated annual incidence of CJD is of 1 case in one million persons, it affects both genders in the same proportion and the peak incidence occurs between the fifth and sixth decades. Its exact incubation time is still unknown, but can range from 12 months up to several years ${ }^{(2,5,8)}$.

There are three different stages of the disease during its clinical evolution:

1. Prodrome - in this stage the patient presents with vague symptoms such as asthenia, depression, sleep disorders, inattention, weight loss, visual complaints/abnormalities, motor incoordination and nystagmus. This stage lasts about 3 to 4 months;

2. Disease stage - symptoms of progressive dementia, behavioral disorders, cognitive compromise, as well as clinical signs of pyramidal, extrapyramidal and cerebellar compromise, as well as those of a lower motor neuron disease comprise the clinical picture. This has a mean duration of 4 to 5 months;

3. Terminal stage - in this end-stage phase the patient progresses to coma with mioclonic jerks, further evolving to abnormal decortication and decerebration postures, seizures and dysautonomic symptoms. The duration varies according to the nursing care administered to the patient ${ }^{(5)}$.

The diagnosis is fundamentally based on the clinical signs, in electroencephalographic findings and in the detection of the 14-3-3 protein in the spinal fluid ${ }^{(2,5,6)}$. However, the definitive diagnosis can only be done based on neuropathologic features, which show neuronal loss, gliosis and vacuolar lesions, giving the characteristic spongiform appearance to the central nervous system in optical microscopy ${ }^{(5)}$.
Electroencephalographic changes also vary along with the different stages of the disease, with the characteristic periodic pattern occurring in as much as 75 to $94 \%$, even tough it might only be found in the later stages (up to 12 weeks) ${ }^{(7)}$.

We report a case of probable sporadic CreutzfeldtJakob's Disease with emphasis on the EEG findings.

\section{CASE REPORT}

A 79 years old white woman first presented to a medical visit complaining of vertigo - like symptoms that started about 45 days prior to her visit. She first consulted with an othorhinolaryngologist who found no abnormalities in his examination and prescribed anti-vertiginous medications. She then had a progressive worsening of her symptoms, associated with bilateral visual impairment, gait compromise and child-like behaviour. Her medical history was unremarkable, except for controlled arterial hypertension, cardiac arrhythmia and a prosthetic replacement of her left knee as a result of severe arthosis.

On examination the patient was disoriented in both time and space, had a gait ataxia, increased deep tendon reflexes and horizontal nystagmus. A previous resonance imaging study had only disclosed a minor volumetric reduction of her brain, which was considered within normal limits for her age. She was then admitted for investigation, during which an EEG was performed as part of the routine evaluation. Her EEG was strikingly abnormal, with high amplitude, generalized delta waves occurring in rhythmic bursts, with a duration of up to 4 seconds, most prominent over the anterior regions, a pattern that was compatible with FIRDA (Frontal Intermittent Rhythmic Delta Activity). A spinal tap was performed, but her spinal fluid had cytological and biochemical findings within normal ranges. No metabolic abnormalities were found. She was then discharged without a clear diagnosis, with planned outpatient visits.

Twelve days later she was once again admitted with a significant worsening of her symptoms, which then included spasticity of all four limbs, an inability to walk and a worsening of her dementia with inability to swallow or talk, emitting only incomprehensible mumbled sounds. A second EEG disclosed periodic triphasic wave complexes, repeating every 0.5 to 1 second, of moderate amplitude, generalized distributed in both hemispheres (Figures 1, 2 and 3 - EEG fragments are counted retrospectively, in relation to date of death).

A new diffusion brain MRI study showed no significant changes when compared with her previous exam. A new spinal tap was performed and a CSF sample was sent to laboratory analysis for 14-3-3 protein and specific-enolase enzyme detection. The former was positive, while the latter was negative. A peripheral blood sample was collected and sent for detection of the mutation of the gene for the PrPC protein, but no such DNA mutation was found. 
Doença de Creutzfeldt-Jakob ...

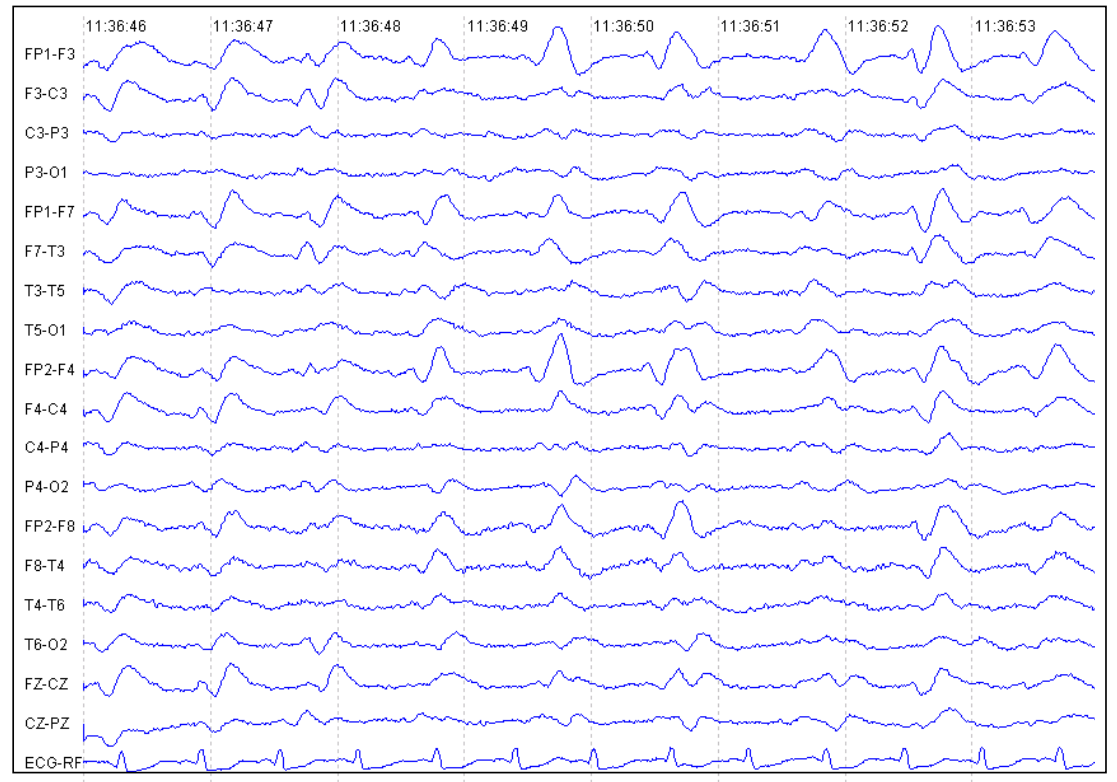

(10) 10:41:08 10:41:11

(1)

Figure 1. Periodic generalized triphasic wave complexes, moderate amplitude, repeating every 0.5 to 1 second. First EEG, during second hospital admission, day -40 .

Figure 2. Periodic generalized triphasic wave complexes, moderate amplitude, during repetitive photic stimulation. Evolutive EEG, day-33.
Figure 3. Periodic generalized triphasic wave complexes, moderate amplitude, at rest. Last EEG day-25. 
During her hospital stay she evolved with coma with frequent mioclonic jerks and rare tonic-clonic seizures. Subsequent EEGs had the same typical pattern, sometimes mixed with diffuse voltage depression. She had several urinary and pulmonary infectious complications during her stay and finally died after 45 days as a result of respiratory insufficiency.

\section{DISCUSSION}

EEG studies play an important role in the investigation and diagnosis of CJD when specific findings are found, thus allowing the clinician to progress in the investigation from a suspected case of CJD to a probable diagnosis status, which also has epidemiological repercutions ${ }^{(8)}$. Typical EEG findings of CJD are generalized complexes, either biphasic or triphasic, lasting for 100 to 300 milliseconds, with a mean amplitude of $300 \mu \mathrm{V}$ and an interval among repetitions of 0.5 to 1.5 seconds $^{(7,8)}$. May proposed, in 1968, a clinical staging for the disease, with a good correlation with EEG evolution ${ }^{(9)}$. In the prodromic phase the clinical symptoms are somewhat vague, such as headache, vertigo, confusion and syncope. In this stage the EEG shows a slowing of background activity, with both theta and delta waves with a generalized bilateral distribution, sometimes predominating over one hemisphere or the other. Also, physiological sleep graph elements are lacking ${ }^{(7,8)}$.

At the beginning of the proper disease phase, another pattern can be found, known as FIRDA (frontal intermittent rhythmic delta activity), which is characterized by high amplitude, 100 a $150 \mu \mathrm{V}$, rhythmic delta waves, most prominent over the anterior regions of the scalp, that present in an intermittent fashion. This pattern is by no means specific, as it can also be found in metabolic encephalopathies and even in patients with focal lesions of the Central Nervous System ${ }^{(4,8)}$. Later, during this same stage, the typical pattern described is time-locked to the mioclonic jerks, as they occur a few milliseconds before or after the electrical discharges ${ }^{(7,8,10)}$. The evolution of FIRDA to periodic complexes might take from 1 to 3 weeks ${ }^{(4)}$. This pattern is better defined when the patient is more alert, and is less defined during sleep ${ }^{(7)}$.

Another feature of the periodic complexes is that they can either be attenuated or disappear after intravenous use of Midazolam ${ }^{(4)}$. Several different theories try to explain the origin of this pattern, which sometimes resembles some patterns that are generated in the thalamocortical axis, such as sleep graphs and $3 \mathrm{~Hz}$ spike-waves in absence epilepsy. However, this periodic pattern can vary in both shape and interval in the same patient ${ }^{(4)}$.

Finally, in the terminal stage the patient develops an akinetic mutism, evolving further to coma and a reduction of the mioclonic jerks; concomitantly, the EEG has a reduction of the periodic complexes until they are no longer visible and are replaced by a diffuse depression of background voltage ${ }^{(7,8)}$.
The typical pattern can be found in as many as 75 to $94 \%$ of all patients ${ }^{(7)}$, and according to Steinhoff, who reported in 2004 a series of 150 patients who underwent necropsy, the EEG has a sensitivity of $64 \%$, specificity of $91 \%$, a positive predictive value of $95 \%$ and a negative predictive value of $49 \%$. In those patients who had a false positive EEG, the autopsy diagnosis were of Alzheimer's Disease in 4 cases and vascular dementia in one case ${ }^{(11)}$. In another study, Zerr et al found a sensitivity of $66 \%$ and a specificity of $74 \%{ }^{(12)}$. On the other hand, it is believed that the in vivo method of diagnosis with the highest sensitivity and specificity ( $94 \%$ and $84 \%$, respectively) is the demonstration of the 14-3-3 protein in the spinal fluid ${ }^{(12)}$.

In 1929 Heidenhain described a variant form of the disease that had initially predominant visual symptoms followed by a rapid evolution. The EEG of such patients had the periodic complexes localized more predominantly over the posterior regions bilaterally ${ }^{(2,8)}$.

Our case illustrates both clinical and electroencephalographic features typical of this rare and fatal disease, with the EEG playing a large role in the diagnosis. We highlight the need for serialized recordings in a suspected case, due to the different evolutive stages of EEG findings and clinical symptoms.

\section{REFERENCES}

1. Moreno-Izco F, Martinez-Gil A. Enfermedad de Creutzfeldt-Jakob: alteración de la señal cortical aislada em resonancia magnética de difusión. Rev Neurol 2005; 40 (1):38-42.

2. Silva AM et al. Estudo Retrospectivo da Doença de CreutzfeldtJakob diagnosticada no Norte de Portugal entre 1993-2002. Arq Neuropsquiatr 2003; 61(4):950-6.

3. Prusiner SB. Novel proteinaceus infectious particles cause scrapie. Science 1982; 216:136-44.

4. Wieser et al. Serial EEG findings in sporadic and iatrogenic Creutzfeldt-Jakob Disease. Clin Neurophysiol 2004; 115(11):2467-78.

5. Yasuda N, Scaff M. Doença de Creutzfeldt-Jakob e encefalopatia espongiforme bovina. In: Encefalopatia espongiforme transmissível: caderno técnico. 1a ed. Brasília; 2004.

6. Arruda WO et al. Doença de Creutzfeldt-Jakob Forma Heidenhain - Relato de caso com achados de ressonância magnética e DWI. Arq Neuropsiquiatr 2004; 62(2-A):347-52.

7. Markand ON. Organic brain syndromes and dementias. In: Current practice of clinical electroencephalography. Daly DD, Pedley TA, editors. New York, NY: Rave press. p. 413-5.

8. Ortega-Albás JJ, Serrano-García AL. Neurofisiologia en la enfermedad de Creutzfeldt-Jakob. Rev Neurol 2003; 36(4):376-80.

9. May WW. Creutzfeldt-Jakob Disease. 1. Survey of the literature and clinical diagnosis. Acta Neurol Scand 1968; 44:1-32.

10. Sun HY, et al The correlation between the electroencephalogram findings and clinical manifestations of Creutzfeldt-Jakob Disease. Zhonghua Yi Xue Za Zhi 2003; 83(17):1510-2.

11. Steinhoff BJ, et al. Diagnostic value of periodic complexes in Creutzfeldt-Jakob Disease. Ann Neurol 2004; 56(5):702-8.

12. Zerr I. Analysis of EEG and CSF 14-3-3 proteins as aids to the diagnosis of Creutzfeldt-Jakob disease. Neurology 2000; 55(6):811-5.

\begin{tabular}{c} 
Mande seu caso para: \\
JECN - A/c. de ANDRÉ PALMINI \\
Av. Montenegro, 186 sala 505 - Petrópolis \\
CEP 90460-160, Porto Alegre, RS, Brasil ou \\
pelo e-mail: jecnpoa@terra.com.br \\
\hline
\end{tabular}

